\title{
Penerapan Diversi Sebagai Upaya Perlindungan Hukum \\ Terhadap Anak Pelaku Tindak Pidana
}

Fiska Ananda*

* Mahasiswa Program Magister (S2) Ilmu Hukum Fakultas Hukum UNISSULA Semarang, email : chafiska@yahoo.com

\begin{abstract}
ABSTRAK
Anak menjadi pelaku tindak pidana selalu meningkat, dalam kasus-kasus tertentu, anak yang menjadi pelaku menjadi perhatian khusus bagi aparat penegak hukum. Salah satu solusi yang dapat ditempuh dalam penanganan perkara tindak pidana anak adalah pendekatan restorative juctice, yang dilaksanakan dengan cara pengalihan (diversi). Diversi dilakukan untuk memberikan perlindungan dan rehabilitasi (protection and rehabilitation) kepada pelaku sebagai upaya untuk mencegah anak menjadi pelaku kriminal dewasa. Diversi terhadap anak pelaku tindak pidana dilaksanakan oleh ketiga komponen sistem peradilan pidana di Indonesia mulai dari kepolisian, kejaksaan hingga pengadilan. Kata Kunci: Diversi, Perlindungan Hukum, Anak.
\end{abstract}

\section{ABSTRACT}

The number of children becoming a perpetrator are always increasing. In some certain cases, children that becoming a culprit are also being a special attention for the law enforcer. One of the solutions that could be taken in handling a children criminal cases is an approach of the restorative justice, which implemented by a diversion way. Diversion could be implemented for providing a protection and rehabilitation (protection and rehabilitation) to the perpetrator on the efforts for prevent the children becoming an adult culprit. Diversion to the children's perpetrator are implemented by the three criminal justice component system in Indonesia including The National Police, The Attorney, until The Court.

Keywords: Diversion, Law Protection, Children.

\section{PENDAHULUAN}

Anak merupakan aset bangsa, sebagai bagian dari generasi muda anak berperan sangat strategis sebagai successor suatu bangsa. Dalam konteks Indonesia, anak adalah penerus cita-cita perjuangan suatu bangsa. Selain itu, anak merupakan harapan orang tua, harapan bangsa dan negara yang akan melanjutkan tongkat estafet pembangunan serta memiliki peran strategis, mempunyai ciri atau sifat khusus yang akan menjamin kelangsungan eksistensi bangsa dan negara pada masa depan. Oleh karena itu, setiap anak harus mendapatkan pembinaan sejak dini, anak perlu mendapat kesempatan yang seluas-luasnya untuk dapat tumbuh dan berkembang secara optimal, baik fisik, mental maupun sosial. Terlebih lagi bahwa masa kanak-kanak merupakan periode pembentukan watak, kepribadian dan karakter diri seorang manusia, agar kehidupan mereka memiliki kekuatan dan kemampuan serta berdiri tegar dalam meniti kehidupan. ${ }^{1}$

Setiap tahun anak yang menjadi pelaku tindak pidana selalu meningkat, dalam kasus-kasus

\footnotetext{
${ }^{1}$ Maidin Gultom, Perlindungan Hukum Terhadap Anak dalam Sistem Peradilan Pidana Anak di Indonesia, Bandung: Refika Aditama, 2008, hal. 1.
} 
tertentu, anak yang menjadi pelaku menjadi perhatian khusus bagi aparat penegak hukum. Oleh karena itu, berbagai upaya pencegahan dan penanggulangan terhadap anak yang berhadapan dengan hukum, perlu segera dilakukan. Salah satu upaya pencegahan dan penanggulangan terhadap anak yang berhadapan dengan hukum saat ini melalui penyelenggaraan sistem peradilan pidana anak. Untuk melaksanakan pembinaan dan memberikan perlindungan terhadap anak, diperlukan dukungan, baik yang menyangkut kelembagaan maupun perangkat hukum yang lebih mantap dan memadai. Oleh karena itu ketentuan mengenai penyelengaraan pengadilan bagi anak perlu dilakukan secara khusus. ${ }^{2}$ Tujuan penyelenggaraan sistem peradilan pidana anak tidak semata-mata bertujuan untuk menjatuhkan sanksi pidana bagi anak pelaku tindak pidana, tetapi lebih difokuskan pada pertanggungjawaban pelaku terhadap korban tindak pidana, demi kesejahteraan anak yang bersangkutan, tanpa mengurangi perhatian kepentingan masyarakat.

Anak yang melakukan pelanggaran hukum atau melakukan tindakan kriminal sangat dipengaruhi beberapa faktor lain di luar diri anak seperti pergaulan, pendidikan, teman bermain dan sebagainya, karena tindak pidana yang dilakukan oleh anak pada umumnya adalah merupakan proses meniru ataupun terpengaruh tindakan negatif dari orang dewasa atau orang disekitarnya. Ketika anak tersebut diduga melakukan tindak pidana, sistem peradilan formal yang ada pada akhirnya menempatkan anak dalam status narapidana tentunya membawa konsekuensi yang cukup besar dalam hal tumbuh kembang anak. Proses penghukuman yang diberikan kepada anak lewat sistem peradilan pidana formal dengan memasukkan anak ke dalam penjara ternyata tidak berhasil menjadikan anak jera dan menjadi pribadi yang lebih baik untuk menunjang proses tumbuh kembangnya. Penjara justru seringkali membuat anak semakin profesional dalam melakukan tindak kejahatan.

Untuk melakukan perlindungan terhadap anak dari pengaruh proses formal sistem peradilan pidana, maka timbul pemikiran manusia atau para ahli hukum dan kemanusiaan untuk membuat aturan formal tindakan mengeluarkan (remove) seorang anak yang melakukan pelanggaran hukum atau melakukan tindak pidana dari proses peradilan pidana dengan memberikan alternatif lain yang dianggap lebih baik untuk anak.

Secara hukum Negara Indonesia telah memberikan perlindungan kepada anak melalui berbagai peraturan perundang-undangan di antaranya Undang-Undang Nomor 3 Tahun 1997 tentang Pengadilan Anak, Undang-Undang Nomor 39 tentang Hak Asasi Manusia dan Undang-Undang Nomor 23 Tahun 2002 tentang Perlindungan Anak. Salah satu solusi yang dapat ditempuh dalam penanganan perkara tindak pidana anak adalah pendekatan restorative juctice, yang dilaksanakan dengan cara pengalihan (diversi). Restorative justice merupakan proses penyelesaian yang dilakukan di luar sistem peradilan pidana (Criminal Justice System) dengan melibatkan korban, pelaku, keluarga korban dan pelaku, masyarakat serta pihak-pihak yang berkepentingan dengan suatu tindak pidana yang terjadi untuk mencapai kesepakatan dan penyelesaian. Restorative justice dianggap cara berfikir/paradigma

\footnotetext{
2 Mohammad Taufik Makarao, dkk, Hukum Perlindungan Anak dan Penghapusan Kekerasan dalam Rumah Tangga, Jakarta: Rineka Cipta, 2013, hal. 1.
} 
baru dalam memandang sebuah tindak kejahatan yang dilakukan oleh seseorang

Proses peradilan pidana anak seringkali menampilkan dirinya sebagai mekanisme yang hanya berorientasi pada penegakan hukum secara formal dan tidak berorientasi pada kepentingan anak. Penegakkan hukum pidana terhadap anak harus mementingkan masa depan anak. Anak yang berkonflik dengan hukum tidak begitu saja terkena pidana penjara, apabila seorang anak yang pernah dipenjara akan timbul stigma negatif dari masyarakat. Pelaksanaan diversi terhadap anak pelaku tindak pidana akan memberikan pemahaman baru terhadap penyidik tanpa harus melakukan perampasan kemerdekaan sehingga penyelesaian perkara anak yang pertama kali melakukan tindak pidana dengan menekankan pemulihan kembali terhadap korban menjadi sebuah alternatif dalam sistem peradilan pidana anak di Indonesia.

Terkait dengan diversi, diversi lahir dengan tujuan untuk memberikan perlindungan bagi hak anak. Diversi muncul dengan tujuan untuk berupaya menghindari stigma jahat pada anak. Dengan diversi para penegak hukum baik di kepolisian, kejaksaan maupun pengadilan diberikan kewenangan untuk mengalihkan proses peradilan keluar dari proses peradilan formal yang ada. Proses penjatuhan pidana dianggap bukanlah solusi terbaik dalam menyelesaikan tindak pidana yang dilakukan oleh anak. Hal ini sesuai dengan tujuan dari pada peradilan pidana itu sendiri yakni agar terwujud peradilan pidana yang benar-benar menjamin perlindungan kepentingan terbaik terhadap anak. Sehingga diversi penting untuk diperhatikan dalam menyelesaikan tindak pidana yang melibatkan anak, karena dengan diversi perlindungan atas hak-hak anak yang bermasalah dengan hukum dapat lebih terjamin serta dapat menghindarkan anak dari stigma negatif sebagai "anak nakal" karena tindak pidana melibatkan anak sebagai pelaku dapat ditangani tanpa perlu melalui proses hukum formal yang ada.

\section{PEMBAHASAN}

\section{Penerapan Diversi Di Indonesia}

Pelaksanaan diversi dilatarbelakangi keinginan menghindari efek negatif terhadap jiwa dan perkembangan anak oleh keterlibatannya dengan sistem peradilan pidana. Pelaksanaan diversi oleh aparat penegak hukum didasari oleh kewenangan aparat penegak hukum yang disebut discretion atau dalam bahasa Indonesia diskresi. Dengan penerapan konsep diversi bentuk peradilan formal yang ada selama ini lebih mengutamakan usaha memberikan perlindungan bagi anak dari tindakan pemenjaraan.

Negara memiliki kewenangan dikresional untuk melakukan pengalihan (diversi) anak yang berkonflik dengan hukum dari proses peradilan pidana formal ke proses perdamaian di luar persidangan. Sedapat mungkin anak dihindari dari tindakan penangkapan, penahanan dan pemenjaraan, hal tersebut seharusnya sebagai upaya terakhir. Diversi merupakan proses diskresi yang dilakukan komponen sistem peradilan pidana (Kepolisian, Kejaksaan, Pihak Pengadilan) yang ditujukan kepada anak yang berkonflik dengan hukum. Diversi merupakan kebijakan yang dilakukan untuk menghindarkan pelaku dari sistem peradilan pidana formal.

Dalam penerapan diversi di Indonesia, terdapat beberapa ketentuan peraturan perundangundangan baik Peraturan Internasional maupun Peraturan Nasional yang dijadikan acuan dalam 
melaksanakan diversi terhadap anak yang berhadapan dengan hukum, khusunya sebagai pelaku adalah:

1. Peraturan Internasional

a. Convenion on the Rights of The Child (Konvensi Hak-Hak Anak).

b. The United Nations Standard Minimum Rules for Administration of Juvenile Justice-the Beijing Rules (Peraturan Standar Minimum PBB untuk Pelaksanaan Peradilan Anak-Peraturan Beijing).

c. The United Nations Rules for the Protection of Juvenile Deprived of Their Liberty (Peraturan PBB untuk Perlindungan Anak yang Terampas kebebasannya)

2. Peraturan Nasional

a. Undang-Undang Republik Indonesia Nomor 2 Tahun 2002 tentang Polisi Republik Indonesia.

b. Undang-Undang Republik Indonesia Nomor 23 tahun 2002 tentang Perlindungan Anak.

c. Undang-Undang Republik Indonesia Nomor 3 Tahun 1997 Tentang Pengadilan Anak.

d. Undang-Undang Republik Indonesia Nomor 11 Tahun 2012 tentang Sistem Peradilan Anak.

e. TR Kabareskrim Nomor 1124/XI/2006 tentang Pedoman Pelaksanaan Diversi Bagi Kepolisian

Diversi dilakukan untuk memberikan perlindungan dan rehabilitasi (protection and rehabilitation) kepada pelaku sebagai upaya untuk mencegah anak menjadi pelaku kriminal dewasa. ${ }^{3}$ Penjelasan umum Undang-Undang Nomor 11 Tahun 2012 tentang Sistem Peradilan Pidana Anak disebutkan bahwa Keadilan restoratif merupakan suatu proses diversi. Artinya semua pihak yang terlibat dalam suatu tindak pidana tertentu bersama-sama mengatasi masalah serta menciptakan suatu kewajiban untuk membuat segala sesuatunya menjadi lebih baik dengan melibatkan korban, anak, dan masyarakat dalam mencari solusi untuk memperbaiki, rekonsiliasi, dan menetramkan hati yang tidak berdasarkan pembalasan.

Undang-Undang Nomor 11 Tahun 2012 tentang Sistem Peradilan Pidana Anak telah mengatur tentang diversi yang berfungsi agar anak yang berhadapan dengan hukum tidak terstigmatisasi akibat proses peradilan yang harus dijalaninya. Hal ini sesuai dengan yang tercantum dalam Resolusi PBB tentang United Nation Standard Minimum Rules for the Administration of Juvenile Justice (The Beijing Rules), apa yang dimaksud dengan diversi adalah pemberian kewenangan kepada aparat penegak hukum untuk mengambil tindakan-tindakan kebijaksanaan dalam menangani atau menyelesaikan masalah pelanggar anak dengan tidak mengambil jalan formal antara lain menghentikan atau meneruskan atau melepaskan dari proses peradilan pidana atau mengembalikan atau menyerahkan kepada masyarakat dan bentuk-bentuk kegiatan pelayanan sosial lainnya. ${ }^{4}$

Dalam Pasal 6 Undang-Undang Nomor 11 Tahun 2012 tentang Sistem Peradilan Pidana Anak menentukan bahwa tujuan dari diversi adalah:

a. Mencapai perdamaian antara korban dan anak.

b. Menyelesaikan perkara anak di luar proses peradilan.

\footnotetext{
${ }^{3}$ Yati Sharfina Desiandri, "Diversi Terhadap Anak yang Berkonflik dengan Hukum di Tingkat Penyidikan", USU Law Journal, Vol. 5 No. 1 (Januari 2017), hal. 147-157.

${ }^{4}$ R. Wiyono, Sistem Peradilan Pidana Anak di Indonesia, Jakarta: Sinar Grafika, 2016, hlm. 47.
} 
c. Menghindarkan anak dari perampasan kemerdekaan.

d. Mendorong masyarakat untuk berpartisipasi.

e. Menanamkan rasa tanggungjawabkepada anak

Sebagai komponen atau subsistem dari sistem peradilan pidana anak, setiap aparatur penegak hukum, yaitu Kepolisian, Kejaksaan dan Pengadilan dalam melaksanakan tugas diversi harus mempunyai tujuan yang sama sebagimana dimaksud oleh Pasal 6 Undang-Undang Nomor 11 Tahun 2012 tentang Sistem Peradilan Pidana Anak. Dimana ketiga komponen tersebut tergabung dalam satu wadah yang sering disebut Sistem Peradilan Pidana (Criminal Justice System), harus mampu berjalan secara bersinergi untuk membangun sistem hukum yang memberikan rasa keadilan dan perlindungan hukum terhadap anak.

Dalam pelaksanaan diversi di Indonesia, terdapat syarat-syarat yang dijadikan pedoman oleh aparat penegak hukum. Adapun syarat-syarat diversi tercantum dalam Undang-Undang Nomor 11 Tahun 2012 Tentang Sistem Peradilan Pidana Anak, Pasal 8 yang menentukan sebagai berikut :

1. Proses Diversi dilakukan melalui musyawarah dengan melibatkan Anak dan orang tua/Walinya, Pembimbing Kemasyarakatan, dan Pekerja Sosial Profesional berdasarkan pendekatan Keadilan Restoratif.

2. Dalam hal diperlukan, musyawarah sebagaimana dimaksud pada ayat (1) dapat melibatkan Tenaga Kesejahteraan Sosial, dan/atau masyarakat.

3. Proses Diversi wajib memperhatikan:
a. Kepentingan korban.
b. Kesejahteraan dan tanggung jawab Anak.
c. Penghindaran stigma negatif.
d. Penghindaran pembalasan.
e. Keharmonisan masyarakat.
f. Kepatutan, kesusilaan, dan ketertiban umum.

Kemudian dalam Pasal 9 Undang-Undang Nomor 11 Tahun 2012 Tentang Sistem Peradilan Pidana Anak, terdapat juga ketentuan mengenai pelaksanaan diversi sebagai berikut:

1. Penyidik, Penuntut Umum, dan Hakim dalam melakukan Diversi harus mempertimbangkan:
a. Kategori tindak pidana.
b. Umur anak.
c. Hasil penelitian kemasyarakatan dari Bapas.
d. Dukungan lingkungan keluarga dan masyarakat.

2. Kesepakatan Diversi harus mendapatkan persetujuan korban dan/atau keluarga Anak Korban serta kesediaan Anak dan keluarganya, kecuali untuk:
a. Tindak pidana yang berupa pelanggaran.
b. Tindak pidana ringan.
c. Tindak pidana tanpa korban.
d. Nilai kerugian korban tidak lebih dari nilai upah minimum provinsi setempat.

Adapun beberapa kriteria tindak pidana yang melibatkan anak sebagai pelaku, yang harus diupayakan penyelesaiannya dengan pendekatan prinsip diversi adalah: 
a. Kategori tindak pidana yang diancam dengan sanksi pidana sampai dengan 1 (satu) tahun harus diprioritaskan untuk diterapkan diversi, tindak pidana yang diancam dengan sanksi pidana di atas 1 (satu) tahun sampai dengan 5 tahun dapat dipertimbangkan untuk melakukan diversi, semua kasus pencurian harus diupayakan penerapan diversi kecuali menyebabkan atau menimbulkan kerugian yang terkait dengan tubuh dan jiwa.

b. Memperhatikan usia pelaku, semakin muda usia pelaku, maka urgensi penerapan prinsip diversi semakin diperlukan.

c. Hasil penelitian dari BAPAS, bila ditemukan faktor pendorong anak terlibat dalam kasus pidana adalah faktor yang ada di luar kendali anak maka urgenitas penerapan prinsip diversi semakin diperlukan.

d. Kerugian yang ditimbulkan oleh tindak pidana anak, bila akibat yang ditimbulkan bersifat kebendaan dan tidak trekait dengan tubuh dan nyawa seseorang maka urgensitas penerapan diversi semakin diperlukan.

e. Tingkat keresahan masyarakat yang diakibatkan oleh perbuatan anak.

f. Persetujuan korban/keluarga.

g. Kesediaan pelaku dan keluarganya.

h. Dalam hal anak melakukan tindak pidana bersama-sama orang dewasa maka orang dewasa harus diproses hukum sesuai dengan prosedur biasa

\section{Perlindungan Hukum Terhadap Anak Pelaku Tindak Pidana}

Konsepsi perlindungan anak meliputi ruang lingkup yang sangat luas, dalam artian dimana perlindungan anak tidak hanya mengenai perlindungan atas jasmani dan rohani anak, tetapi juga mengenai perlindungan atas semua hak dan kepentingannya yang dapat menjamin pertumbuhan dan perkembangan yang wajar, baik secara rohani, jasmani maupun sosialnya. Dimana kedudukan anak sebagai generasi muda yang akan meneruskan cita-cita luhur bangsa, calon-calon pemimpin bangsa dimasa mendatang dan sebagai sumber harapan bagi generasi terdahulu perlu mendapat kesempatan seluas-luasnya untuk tumbuh dan berkembang dengan wajar baik secara rohani, jasmani dan sosial.

Dalam Undang-Undang Nomor 11 Tahun 2012 tentang Sistem Peradilan Pidana Anak mendefenisikan anak di bawah umur sebagai anak yang telah berumur 12 tahun tetapi belum berumur 18 tahun, dan membedakan anak yang terlibat dalam suatu tindak pidana dalam tiga kategori:

a. Pasal 1 angka 3 Undang-Undang Nomor 11 Tahun 2012 tentang Sistem Peradilan Pidana Anakmenyatakan bahwa anak yang berkonflik dengan hukum yang selanjutnya disebut anak adalah anak yang telah berumur 12(duabelas)tahun, tetapi belum berumur 18(delapanbelas) tahun yang diduga melakukan tindak pidana.

b. Pasal 1 angka 4 Undang-Undang Nomor 11 Tahun 2012 tentang Sistem Peradilan Pidana Anak menyatakan bahwa anak yang menjadi korban tindak pidana yang selanjutnya disebut anak korban adalah anak yang belum berumur 18 (delapanbelas) tahun yang mengalami penderitaan fisik, mental, dan/atau kerugian ekonomi yang disebabkan oleh tindak pidana.

c. Pasal 1 angka 5 Undang-Undang Nomor 11 Tahun 2012 tentang Sistem Peradilan Pidana Anak 
menyatakan bahwa anak yang menjadi saksi tindak pidana yang selanjutnya disebut anak saksi adalah anak yang belum berumur 18 (delapanbelas) tahun yang dapat memberikan keterangan guna kepentingan penyidikan, penuntutan dan pemeriksaan di sidang pengadilan tentang suatu perkara tindak pidana yang didengar, dilihat, dan/atau dialaminya sendiri.

Pasal 1 angka 1 Undang-Undang Nomor 35 Tahun 2014 tentang Perubahan Undang-Undang Nomor 23 Tahun 2002 tentang Perlindungan Anak menyatakan bahwa anak adalah seseorang yang belum berusia 18 (delapan belas) tahun, termasuk anak yang masih dalam kandungan. Perlindungan anak merupakan usaha dan kegiatan seluruh lapisan masyarakat dalam berbagai kedudukan dan peranan yang menyadari betul pentingnya anak bagi nusa dan bangsa di kemudian hari. ${ }^{5}$

Dalam upaya memberikan perlindungan terhadap kepentingan dan hak-hak anak yang berhadapan dengan hukum, Pemerintah Indonesia telah mengeluarkan beberapa peraturan perundang-undangan terkait, antara lain UU Nomor 39 Tahun 1999 tentang Hak Asasi Manusia, UU Nomor 3 Tahun 1997 tentang Peradilan Anak dan UU Nomor 23 Tahun 2003 tentang Perlindungan Anak. Masalah perlindungan hak-hak anak yang berhadapan dengan hukum, yang terdapat dalam Pasal 66 Undang-Undang Nomor 39 Tahun 1999, menentukan bahwa:

a. Setiap anak berhak untuk tidak dijadikan sasaran penganiayaan, penyiksaan atau penjatuhan hukuman yang tidak manusiawi.

b. Hukuman mati atau hukuman seumur hidup tidak dapat dijatuhkan untuk pelaku tindak pidana yang masih anak.

c. Setiap anak berhak untuk tidak dirampas kebebasannya secara melawan hukum.

d. Penangkapan, penahanan atau pidana penjara anak hanya boleh dilakukan sesuai dengan hukum yang belaku dan hanya dapat dilaksanakan sebagai upaya terakhir.

e. Setiap anak yang dirampas kebebasannya berhak mendapatkan perlakuan secara manusiawi dan dengan memperhatikan kebutuhan pengembangan pribadi sesuai dengan usianya dan harus dipisahkan dari orang dewasa, kecuali demi kepentingannya.

f. Setiap anak yang dirampas kebebasannya berhak memperoleh bantuan hukum atau bantuan lainnya secara efektif dalam setiap tahapan upaya hukum yang berlaku.

g. Setiap anak yang dirampas kebebasannya berhak untuk membela diri dan memperoleh keadilan di depan Pengadilan Anak yang objektif dan tidak memihak dalam sidang yang tertutup untuk umum.

Dalam Pasal 59 Undang-Undang No. 23 Tahun 2002 tentang Perlindungan Anak, dinyatakan bahwa: "Pemerintah dan Lembaga negara lainnya wajib memberikan perlindungan khusus kepada anak dalam situasi darurat, anak yang berhadapan dengan hukum, anak dari kelompok minoritas dan terisolasi, anak yang tereksploitasi secara ekonomi dan atau seksual, anak yang diperdagangkan, anak yang menjadi korban penyalahgunaan narkotika, alkohol, psikotropika dan zat adiktif lainnya, anak korban penculikan, penjualan dan perdagangan, anak korban kekerasan baik fisik dan atau mental, anak yang menyandang cacat, dan anak korban perlakuan salah dan penelantaran."

Dalam salah satu poin pasal tersebut menyebut tentang anak yang berhadapan dengan hukum. Asumsi setiap orang jika mendengar kata anak yang berhadapan dengan hukum seolah

\footnotetext{
${ }^{5}$ Maidin Gultom, Op. Cit., hal. 33
} 
terkooptasi pada pemahaman anak yang menjadi pelaku tindak pidana. Padahal telah dinyatakan secara tegas dalam Pasal 64 Undang-Undang Nomor 23 Tahun 2002 tentang Perlindungan Anak tersebut bahwa: "Perlindungan khusus bagi anak yang berhadapan dengan hukum sebagaimana dimaksud dalam pasal 59 meliputi anak yang berkonflik dengan hukum dan anak korban tindak pidana. Perlindungan khusus terhadap anak yang berhadapan dengan hukum dilaksanakan melalui:

a. Perlakuan atas anak secara menusiawi sesuai dengan martabat dan hak-hak anak.

b. Penyediaan Petugas Pendamping sejak dini.

c. Penyediaan sarana dan prasarana khusus.

d. Penjatuhan sanksi yang tepat untuk kepentingan yang terbaik bagi anak.

e. Pemantauan dan pencatatan terus menerus terhadap perkembangan anak yang berhadapan dengan hukum.

f. Pemberian jaminan untuk mempertahankan hubungan dengan orangtua atau keluarga.

g. Perlindungan dari pemberian identitas melalui media masa untuk menghindari labelisasi.

Terkait upaya perlindungan hukum bagi anak khususnya yang bermasalah dengan hukum, dalam Undang-undang Nomor 11 Tahun 2012 tentang Sistem Peradilan Pidana Anak telah diatur khusus mengenai diversi dan keadilan restoratif dalam penyelesaian perkara anak yang tentunya dengan tujuan agar hak-hak anak dalam hal ini yang bermasalah dengan hukum lebih terlindungi dan terjamin. Dimana dalam UU ini diatur bahwa pada tingkat penyidikan, penuntutan dan pemeriksaan perkara Anak di pengadilan negeri wajib diupayakan Diversi. ${ }^{6}$

a. Diversi pada tahap penyidikan

Kepolisian merupakan pintu gerbang utama atau pertama dari sistem peradilan pidana anak dan merupakan pihak pertama yang berwenang menentukan posisi seorang anak yang bermasalah dengan hukum. Sesuai dengan yang diatur dalam Undang-undang sistem peradilan pidana anak Pasal 7 secara jelas menyatakan bahwa penyidik wajib mengupayakan diversi. Penyidik dalam hal ini wajib mengupayakan diversi dalam waktu paling lama 7 (tujuh) hari setelah penyidikan dimulai. Proses diversi dilaksanakan paling lama 30 (tiga puluh) hari setelah dimulainya diversi. Selanjutnya, dalam hal proses diversi berhasil mencapai kesepakatan, Penyidik menyampaikan berita acara diversi beserta kesepakatan diversi kepada ketua pengadilan negeri untuk dibuat penetapan. Serta dalam hal diversi gagal, Penyidik wajib melanjutkan penyidikan dan melimpahkan perkara ke Penuntut Umum dengan melampirkan berita acara diversi dan laporan penelitian kemasyarakatan. $^{7}$

b. Diversi pada tahap penuntutan

Sebagaimana prinsip Welfare Approach (Pendekatan kesejahteraan) dalam penanganan Juvenile Delinquency dan sesuai dengan ketentuan Undang-undang Sistem Peradilan Pidana Anak, Jaksa sebagai Penuntut Umum secara jelas mempunyai hak melakukan diversi, dimana Penuntut Umum wajib mengupayakan diversi paling lama 7 (tujuh) hari setelah menerima berkas perkara dari Penyidik dan diversi dilaksanakan paling lama 30 (tiga puluh) hari. Jika proses diversi berhasil

\footnotetext{
${ }^{6}$ Lihat Pasal 7 Ayat (1) Undang-Undang Sistem Peradilan Pidana Anak.

${ }^{7}$ Lihat Pasal 29 Ayat (1), (2),(3) Undang-Undang Sistem Peradilan Pidana Anak.
} 
mencapai kesepakatan, Penuntut Umum menyampaikan berita acara diversi beserta kesepakatan diversi kepada ketua pengadilan negeri untuk dibuat penetapan. Dan dalam hal diversi gagal, Penuntut Umum wajib menyampaikan berita acara diversi dan melimpahkan perkara ke pengadilan dengan melampirkan laporan hasil penelitian kemasyarakatan. ${ }^{8}$

c. Diversi pada tahap pemeriksaan pengadilan

Anak yang bermasalah dengan hukum pada setiap proses peradilan, baik ketika berurusan dengan polisi, jaksa maupun ketika dalam persidangan pengadilan, pada dasarnya memiliki hak untuk terlindungi hak-haknya sebagai tersangka anak. Sebagaimana yang telah diuraikan terdahulu, bahwa diversi melalui pendekatan restorative justice adalah suatu penyelesaian perkara anak secara adil yang melibatkan pelaku, korban, keluarga mereka dan pihak lain yang terkait dalam suatu perkara pidana, secara bersama-sama mencari penyelesaian terhadap tindak pidana tersebut dan implikasinya, dengan menekankan pemulihan kembali kepada keadaan semula. ${ }^{9}$

Penerapan diversi sebagai tujuan mewujudkan keadilan restoratif sudah tercantum dalam sistem peradilan pidana anak di Indonesia, pada hakikatnya sistem peradilan pidana anak harus ditujukan untuk melindungi hak-hak dan kepentingan anak. Atas dasar hal tersebut dapat dikatakan bahwa proses peradilan pidana anak untuk penjatuhan pidana adalah ultimum remedium dan bukan primum remedium, tujuan proses peradilan pidana anak bukanlah ditujukan pada penghukuman, melainkan perbaikan kondisi, pemeliharaan dan perlindungan anak serta pencegahan pengurangan tindakan pengadilan yang konstruktif. ${ }^{10}$

Sistem peradilan pidana anak yang diperuntukkan terhadap anak yang berhadapan dengan hukum tetap memperhatikan kepentingan terbaik baik anak tanpa merampas hak asasi anak dan supaya anak tidak mendapatkan stigmatisasi negatif dari adanya proses peradilan. Sebenarnya proses pengadilan dibentuk oleh negara untuk menyelesaikan konflik yang muncul dalam masyarakat dan bersifat netral. Akan tetapi pengadilan bukanlah satu-satunya institusi dalam menyelesaikan konflik, karena pihak-pihak yang berkonflik tidak selamanya menggunakan mekanisme penyelesaian pada badan peradilan ${ }^{11}$ seperti penyelesaian anak yang berhadapan dengan hukum dengan jalur diluar pengadilan.

\section{PENUTUP}

\section{Kesimpulan}

a. Diversi merupakan penyelesaian perkara anak yang dilakukan di luar peradilan formal dengan tujuan menghindarkan dari stigmatisasi Anak yang Berhadapan dengan Hukum (ABH). Diversi terhadap anak yang berhadapan dengan hukum telah diatur dalam Undang-Undang Nomor 11 Tahun 2011 tentang Sistem Peradilan Pidana Anak yang telah menggantikan Undang-Undang Nomor 3 Tahun 1997 tentang Pengadilan Anak, sedangkan tujuan diterapkannya diversi yaitu

\footnotetext{
${ }^{8}$ Lihat Pasal 42 Undang-Undang Sistem Peradilan Pidana Anak

${ }^{9}$ Abintoro Prakoso, Pembaruan Sistem Peradilan Pidana Anak, Yogyakarta: Laksbang Grafika, 2012, hal. 234.

${ }^{10}$ Dwidja Priyatno, Wajah Hukum Pidana Asas dan Perkembangan, Bekasi: Gramata Publishing, 2012, hal. 308.

11 Trisno Raharjo, Mediasi Pidana dalam Sistem Peradilan Pidana Suatu Kajian Perbandingan dan Penerapannya di Indonesia, Yogyakarta: Mata Padi Pressindo, 2011, hlm. 21
} 
untuk menghindari dan menjauhkan anak dari proses peradilan sehingga dapat menghindari stigmatitasi terhadap anak yang berhadapan dengan hukum dan diharapkan anak dapat kembali ke lingkungan sosial secara wajar.

b. Diversi terhadap anak pelaku tindak pidana dilaksanakan oleh ketiga komponen sistem peradilan pidana di Indonesia mulai dari kepolisian, kejaksaan hingga pengadilan dengan harapan mampu memberikan perlindungan hukum terhadap anak.

\section{Saran}

a. Masyarakat dan orangtua sebaiknya turut serta dalam upaya memberikan perlindungan terhadap anak dengan memenuhi hak-hak anak, melindungi sebaik-baikya kepentingan anak, serta semakin meningkatkan pengawasan terhadap lingkungan dan tempat bermain anak sehingga dapat menjauhkan anak dari keterlibatan dalam suatu tindak pidana (anak berhadapan dengan hukum).

b. Diharapkan ketiga komponen sistem peradilan pidana di Indonesia mampu bekerja secara bersinergi agar mampu memberikan perlindungan hukum terhadap anak.

\section{DAFTAR PUSTAKA}

Desiandri, Yati Sharfina 2017, "Diversi Terhadap Anak yang Berkonflik dengan Hukum di Tingkat Penyidikan", USU Law Journal, Vol. 5 No. 1.

Gultom, Maidin, 2008, Perlindungan Hukum Terhadap Anak dalam Sistem Peradilan Pidana Anak di Indonesia, Bandung: Refika Aditama.

Makarao, Mohammad Taufik dkk, 2013, Hukum Perlindungan Anak dan Penghapusan Kekerasan dalam Rumah Tangga, Jakarta: Rineka Cipta.

Prakoso, Abintoro, 2012, Pembaruan Sistem Peradilan Pidana Anak, Yogyakarta: Laksbang Grafika.

Priyatno, Dwidja, 2012, Wajah Hukum Pidana Asas dan Perkembangan, Bekasi: Gramata Publishing.

Raharjo, Trisno, 2011, Mediasi Pidana dalam Sistem Peradilan Pidana Suatu Kajian Perbandingan dan Penerapannya di Indonesia, Yogyakarta: Mata Padi Pressindo.

Undang-Undang Nomor 11 Tahun 2012 tentang Sistem Peradilan Pidana Anak.

Wiyono, R., 2016, Sistem Peradilan Pidana Anak di Indonesia, Jakarta: Sinar Grafika. 